\title{
Clinical, Microbiological and Radiological Characterises of Lower Respiratory tract Infection in Children with Established Congenital Heart Diseases.
}

\author{
Bhaskar S. ${ }^{1}$, Afzal K M. ${ }^{2 *}$, Babu R M. ${ }^{3}$, Subramanya NK. ${ }^{4}$ \\ DOI: https://doi.org/10.17511/ijpr.2021.i04.03
}

\footnotetext{
${ }^{1}$ Sandeep Bhaskar, Associate professor, Department of Pediatrics, Vydehi Institute Of medical sciences, Bangalore, Karnataka, India.

${ }^{2 *}$ Afzal K M, Senior Resident, Department of Pediatrics, Vydehi Institute of Medical Sciences, Bangalore, Karnataka, India.

3 Manjunatha Babu R, Professor, Department of Pediatrics, Akash Institute of medical sciences, Devanahalli, Karnataka, India.

${ }^{4}$ Subramanya NK, Professor, Department of Pediatrics, Vydehi Institute Of medical sciences, Bangalore, Karnataka, India.
}

Introduction: Acute Lower Respiratory Tract Infection (ALRTI) is the most common cause of death in children under five. Various demographic, socio-economic and environmental factors have been associated with ALRTI, with conflicting results. Children with congenital heart diseases are more vulnerable to lower respiratory tract infections following the fact that they had an anatomical defect that causes hemodynamic disturbance of lung circulation and mucosal oedema finally leads to decreased lung compliance and recurrent lower respiratory tract infections. Methods: Children aged between 1 month and 18 years with clinically established congenital heart disease confirmed by echocardiography and presenting with signs and symptoms suggestive of lower respiratory tract infection were enrolled in the study. A detailed history was taken and routine blood investigations were done in all cases. Chest X-Ray was done to confirm the clinical diagnosis. Results: Mean age of the study subjects was 2 years. VSD was seen in $64.9 \%$ of cases while $10.5 \%$ of cases had VSD and ASD. The most common presenting symptoms were: cough $(98.2 \%)$, reduced feeding $(97.4 \%)$, fever $(89.5 \%)$, running nose $(67.5 \%)$ and wheeze $(49.1 \%)$. Leucocytosis and raised ESR were seen in $66.7 \%$ and $64.9 \%$ cases respectively. In Throat swab Commensals were seen in $36 \%$ of cases while gram-positive cocci were seen in $3.5 \%$ cases respectively. In blood culture Streptococcus pneumoniae being the commonest organism isolated. Bilateral and unilateral opacities on chest $\mathrm{x}-$ ray were seen in $16.7 \%$ and $12.3 \%$ cases respectively. Conclusion: Bronchopneumonia was the commonest LRTI in children with the predominance of VSD.

Keywords: LRTI, Congenital heart disease, Chest X-ray

Corresponding Author

Afzal K M, Senior Resident, Department of Pediatrics, Vydehi Institute of Medical Sciences, Bangalore, Karnataka, India.

Email: drafsal2021@gmail.com
How to Cite this Article

To Browse

Bhaskar S, Afzal K M, Babu RM, Subramanya NK.

Clinical, Microbiological and Radiological Characterises of Lower Respiratory tract Infection in Children with Established Congenital Heart Diseases.. Pediatric Rev Int J Pediatr Res. 2021;8(4):182-188. Available From

https://pediatrics.medresearch.in/index.php/ijpr/arti

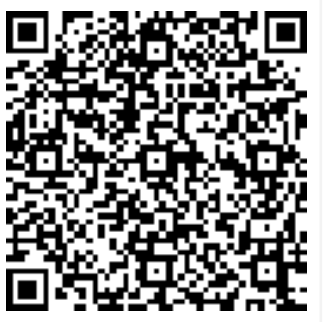
cle/view/693
Manuscript Received 2021-06-24

Conflict of Interest No
Review Round 1 2021-07-04

Funding

Review Round 2
2021-07-14
Ethical Approval
Yes

Review Round 2

Yes
Review Round 3 2021-07-26

Plagiarism X-checker $7 \%$
Accepted 2021-08-19

Note

(C) 2021 by Sandeep Bhaskar, Afzal K M, Manjunatha Babu R, Subramanya NK and Published by Siddharth Health Research and Social Welfare Society. This is an Open Access article licensed under a Creative Commons Attribution 4.0 International License https://creativecommons.org/licenses/by/4.0/ unported [CC BY 4.0]. 


\section{Introduction}

Acute Lower Respiratory Tract Infection (ALRTI) is the most common cause of death in children under five. Acute respiratory infections (ARI) result in 1.9 million childhood deaths per year in developing countries and $20 \%$ of these deaths are from India [1]. Epidemiological factors and the disease burden differ in developing and industrialised countries [26]: in industrialised countries morbidity predominates, whereas in developing countries mortality due to acute lower respiratory tract infections (ALRTI) is a significant problem, along with considerable morbidity and hospitalisations, particularly in children aged $<5$ years.

Various demographic, socio-economic and environmental factors have been associated with ALRTI, with conflicting results [2-7]. Congenital heart disease is primarily a disease condition of infant's neonates and children. Out of all congenital anomalies, congenital heart disease is the leading condition of mortality and morbidity in children under 5 years of age [8]. Often the circulatory derangement also places stress on the respiratory system itself [9]. Children with congenital heart diseases are more vulnerable to lower respiratory tract infections following the fact that they had an anatomical defect that causes hemodynamic disturbance of lung circulation such as pulmonary over circulation, increased capillary wedge pressure and left atrial pressure which results in luminal narrowing and mucosal oedema finally leads to decreased lung compliance and recurrent lower respiratory tract infections [10].

There is a conflict among study results regarding the vulnerability of children with CHD for LRTI [1113]. also there is a paucity of such studies in the Indian setting. Hence this study is taken up to evaluate clinical, radiological \& microbiological characteristics of lower respiratory tract infection in children with CHD.

\section{Material \& Methods}

Setting: This study was conducted at a tertiary care medical teaching hospital.

Duration and Type of Study: This study was done over two and half years. This was a Hospital-based Cross-sectional study.

Sampling Methods: A consecutive type of nonprobability sampling was used during the study.
Sample Size Calculation: A consecutive type of non-probability sampling was used during the study. A total of 114 children between the age of 1 month and 18 years attending the outpatient/inpatients in our hospital.

\section{Inclusion Criteria}

01 . Children from 1 month to 18 years of age.

02. Children with established congenital heart diseases as proved by echocardiography.

03. Infant and children with clinical signs and symptoms of the lower respiratory tract infection.

\section{Exclusion Criteria}

01. Children already operated for congenital heart disease

02. Children with signs and symptoms of upper respiratory tract infections.

03. Children less than 1 month and greater than 18 years of age.

04. Those who are unwilling to get an x-ray, blood tests, microbiological tests

Data Collection Procedure: Children's with clinically established congenital heart disease confirmed by echocardiography and presenting with signs and symptoms suggestive of lower respiratory tract infection were enrolled in the study. A detailed history was taken and routine blood investigations such as CBC, CRP, ESR was done in all cases. Chest $X$-Ray was done in these children to assess the portion of lung involvement and toconfirm the clinical diagnosis. Sputum culture along with blood culture was performed in selected children for microbiological evaluation and confirmation of particular pathogen causing the lower respiratory tract infections.

Any Scoring System used- Nil.

Surgical Procedure if any -Nil

Statistical Analysis: The quantitative data was represented as their mean \pm SD. Categorical and nominal data were expressed in percentage. All analysis was carried out by using SPSS software version 21 .

\section{Results}

A total of 114 children were included in the final analysis. The mean age of the study subjects was 2 years with $43.9 \%$ of the cases being 1 year or less and $53.5 \%$ cases were between $1-5$ years of life 
[Table .1]. Out of the total 114 cases, $67.5 \%$ were males and $32.5 \%$ were females [Fig.1]. VSD was seen in $64.9 \%$ of cases while $10.5 \%$ of cases had VSD and ASD. Isolated ASD and PDA were seen in $12.3 \%$ of cases [Table.2]. Most common presenting symptoms were: cough (98.2\%), reduced feeding $(97.4 \%)$, fever $(89.5 \%)$, running nose $(67.5 \%)$ and wheeze (49.1\%) [Table.2]. Inter-costal indrawing and subcostal indrawing were seen in $36 \%$ and $40.4 \%$ cases while both inter-costal and sub-costal indrawing were seen in $23.7 \%$ of cases [Table.2]. In lab investigations, Leucocytosis and raised ESR were seen in $66.7 \%$ and $64.9 \%$ cases respectively. Positive CRP was seen in $8.8 \%$ of cases [Table.2]. In Throat swab Commensals were seen in $36 \%$ cases while gram-positive cocci were seen in 3.5\% cases respectively [Table.2]. Blood culture was done in 25 cases with Streptococcus pneumoniae being the commonest organism isolated (n-16) [Table.2]. Bilateral and unilateral opacities on chest x-ray were seen in $16.7 \%$ and $12.3 \%$ cases respectively. Bronchopneumonia was diagnosed in $57.9 \%$ of cases while Bronchiolitis and Lobar pneumonia was diagnosed in $33.3 \%$ and $8.8 \%$ cases respectively. IV antibiotics were required in $92.1 \%$ of cases while oral antibiotics were given in $7.9 \%$ of cases [Table.2].

Table 1. Distribution of cases as per age group

\begin{tabular}{|l|l|l|}
\hline \multicolumn{1}{|c|}{ Age group $(\mathrm{yrs})$} & \multicolumn{1}{|c|}{ N } & \multicolumn{1}{c|}{$\%$} \\
\hline & 50 & $43.9 \%$ \\
\hline $1-5$ years & 61 & $53.5 \%$ \\
\hline $6-10$ years & 3 & $2.6 \%$ \\
\hline Total & 114 & $100.0 \%$ \\
\hline Mean age $-2.0+/-1.68$ years & \\
\hline
\end{tabular}

Figure.1. Distribution of cases as per Gender

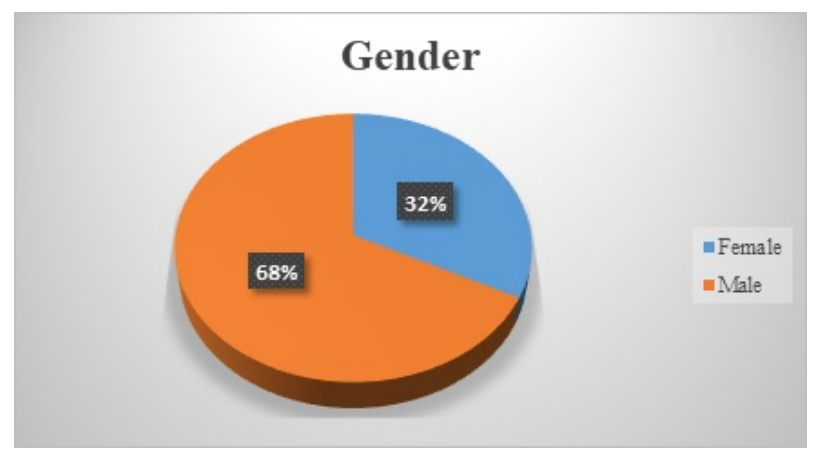

Table.2: Clinical and lab parameters

\begin{tabular}{|l|l|c|l|}
\hline \multicolumn{2}{|c|}{ Clinical \& Laboratory parameters } & N & $\%$ \\
\hline \multirow{3}{*}{ Type of CHD } & ASD & 14 & 12.3 \\
\cline { 2 - 5 } & PDA & 14 & 12.3 \\
\cline { 2 - 4 } & VSD & 74 & 64.9 \\
\cline { 2 - 4 } & VSD, ASD & 12 & 10.5 \\
\hline
\end{tabular}

\begin{tabular}{|c|c|c|c|}
\hline \multirow[t]{5}{*}{ Symptoms } & Fever & 102 & $89.5 \%$ \\
\hline & Cough & 112 & $98.2 \%$ \\
\hline & Running Nose & 77 & $67.5 \%$ \\
\hline & Wheeze & 56 & $49.1 \%$ \\
\hline & Reduced Feeding & 111 & $97.4 \%$ \\
\hline \multirow[t]{3}{*}{ Chest indrawing } & Inter-costal & 41 & $36.0 \%$ \\
\hline & Sub-costal & 46 & $40.4 \%$ \\
\hline & Both & 27 & $23.7 \%$ \\
\hline \multirow[t]{3}{*}{ Lab Investigations } & Leucocytosis & 76 & $66.7 \%$ \\
\hline & ESR Raised & 74 & $64.9 \%$ \\
\hline & Positive CRP & 10 & $8.8 \%$ \\
\hline \multirow[t]{3}{*}{ Throat Swab } & None & 69 & $60.5 \%$ \\
\hline & Commensal & 41 & $36.0 \%$ \\
\hline & Gram Positive Cocci & 4 & $3.5 \%$ \\
\hline \multirow[t]{6}{*}{ Blood Culture } & Not Done & 89 & $78.1 \%$ \\
\hline & Hemophilus influenza & 4 & $3.5 \%$ \\
\hline & Staphylococcus aureus & 1 & $0.9 \%$ \\
\hline & Streptococcus pneumoniae & 16 & $14.0 \%$ \\
\hline & Streptococcus viridans & 3 & $2.6 \%$ \\
\hline & No growth & 1 & $0.9 \%$ \\
\hline \multirow[t]{3}{*}{ Chest $\mathrm{X}$ ray } & Not Significant & 81 & $71.1 \%$ \\
\hline & b/I Opacities & 19 & $16.7 \%$ \\
\hline & u/l Opacities & 14 & $12.3 \%$ \\
\hline \multirow[t]{3}{*}{ Final Diagnosis } & Bronchiolitis & 38 & $33.3 \%$ \\
\hline & Bronchopneumonia & 66 & $57.9 \%$ \\
\hline & Lobar pneumonia & 10 & $8.8 \%$ \\
\hline \multirow[t]{2}{*}{ Antibiotics } & IV & 105 & $92.1 \%$ \\
\hline & Oral & 9 & $7.9 \%$ \\
\hline
\end{tabular}

\section{Discussion}

LRTI are defined in the International Classification of Diseases as infections that affect airways below the epiglottis [14]. Some children have predisposing risk factors such as prematurity, CHD, chronic lung disease, immune disorders, being below 5 years of age, environmental smoke exposure, oropharyngeal incoordination with Aspiration syndrome [15-18]. The incidence of CHD differs for populations and the most common type of CHD is VSD [19]. Children with hemodynamically significant-CHD (HS-CHD) with congestive heart failure are more at risk for LRTI causing mortality and morbidity [20-22]. Some kind of CHD that leads to increased pulmonary flow (e.g.VSD, PDA) or CHD with desaturation (e.g. TOF, DORV, truncus arteriosus) carries a higher risk of recurrent respiratory tract infections and increased frequency of hospitalizations [23].

Type of CHD: In our study VSD were seen in $64.9 \%$ of cases while $10.5 \%$ cases had VSD and ASD. Isolated ASD and PDA were seen in $12.3 \%$ of cases. 
The commonest CHD was ventricular septal defect $(50.00 \%)$ in the study by Sadoh et al. [22]. while in the study by Gabriela $K$ et al. [24]. The most common types of CHD were Patent Ductus Arteriosus $(47.6 \%)$, followed by Ventricular Septal Defect (47\%). Singh PK et al. [25]. in their study observed VSD in $43.6 \%$ cases while $7.7 \%$ cases had VSD and ASD. Isolated ASD and PDA were seen in $28.2 \%$ and $17.9 \%$ cases respectively. Pongiglione G et al. [23]. a similar study observed the most frequent heart defects as a ventricular septal defect $(23.1 \%)$ and coarctation of the aorta (14.3\%).

Demography: Mean age of the study subjects was 2 years with $43.9 \%$ of the cases being 1 year or less and $53.5 \%$ cases were between $1-5$ years of life. In the present study $67.5 \%$ were males and $32.5 \%$ were females. Sadoh et al. [22]. in their study evaluated the contribution of CHD to pneumonia in children seen in a tertiary hospital. There were 121 children with pneumonia of which $61(50.40 \%)$ were males and their mean age was $10.2 \pm 10.93$ months. Singh PK et al. [25]. studied a total of 43 patients with CHD and recurrent LRTI with $53.4 \%$ males and $46.5 \%$ females. Sahan oY et al. [26]. evaluated 50 children who had congenital heart disease and were hospitalized with lower respiratory tract infections. There were 26 boys and 24 girls. The average age of the cyanotic group was $23.88 \pm 28.81$, and the acyanotic group was $12.25 \pm 15.45$ months old. Gabriela K et al. [24]. their study also observed the majority of children $(80 \%)$ being under 1 year of age.

Presenting Complaints: Symptoms and signs of pneumonia may be subtle, particularly in infants and young children. The combination of fever and cough is suggestive of pneumonia; other respiratory findings (eg, tachypnea, increased work of breathing) may precede the cough. Neonates and young infants may present with difficulty feeding, restlessness, or fussiness rather than with cough and/or abnormal breath sounds [27]. In the present study, the most common presenting symptoms were: cough $(98.2 \%)$, reduced feeding $(97.4 \%)$, fever $(89.5 \%)$, running nose $(67.5 \%)$ and wheeze (49.1\%). Gabriela $\mathrm{K}$ et al. [24]. in their study clinical symptoms mostly found where the difficulty of breathing $(98 \%)$, fever $(85.2 \%)$, cough $(75.2 \%)$, and runny nose $(63.1 \%)$. Similarly in the study by Sadoh et al. [22]. and Singh PK et al. [25]. The most common presenting complaints were cough and fever. In a multicenter population-based study that included 2358 children $<18$ years hospitalized
With radiographic evidence of pneumonia, 95 percent had a cough, 90 percent had a fever, 75 percent had anorexia, 70 percent had dyspnea, and 55 percent had chest indrawing [28].

Investigations: Most common investigation finding in pneumonia cases in neonates, young infants, and young children (ie, $<5$ to 10 years of age) is leukocytosis followed by raised acute phase reactants (ESR \& CRP) $[29,30]$. In the present study, leucocytosis and raised ESR were seen in $66.7 \%$ and $64.9 \%$ cases respectively while positive CRP was seen in $8.8 \%$ cases. Gabriela K et al. [24]. a similar study observed leukocytosis in $81 \%$ of cases. Chest X-ray image inpatient with ALRTI can be in the form of mild infiltrate in one lung until extensive consolidation in both lungs. The presence of infiltrates and the increase of Broncho vascular pattern are specific radiologic findings for bronchopneumonia [2]. In the present study infiltration was observed in one-third of the cases which is lower $(80 \%)$ than that observed in the study by Gabriela K et al. [24].

Organism: Viruses are the most common etiology of CAP in older infants and children younger than five years of age [28,31]. However, bacterial pathogens, including S. pneumoniae, S. aureus, and S. pyogenes, also are important because they are associated with increased morbidity and mortality $32,33,34$ ]. Studies have shown that S. pneumoniae is the single most common bacterial pathogen causing pneumonia in all patients beyond the first few weeks of life [35]. In the present study, blood culture was positive in 25 cases $(21.9 \%)$ with Streptococcus pneumoniae being the commonest organism isolated ( $n-16)$. Medrano $C$ et al. [36]. a similar study observed infectious agents in 37 cases $(35.2 \%)$ with the respiratory syncytial virus in 25 , Streptococcus pneumoniae in 5 , and Haemophilus influenza in 4 cases. Srinivasa $S$ et al. [37]. in their study observed the most common pathogen was streptococcus pneumonia followed by klebsiella.

Diagnosis: Among LRTI in children, most of the cases were bronchopneumonia followed by bronchiolitis and lobar pneumonia. In the present study, out of the total 114 studied cases, bronchopneumonia was diagnosed in $57.9 \%$ of cases while Bronchiolitis and lobar pneumonia was diagnosed in $33.3 \%$ and $8.8 \%$ cases respectively. Gabriela K et al. [24]. in their study of 149 children with CHD observed Bronchopneumonia (86.6\%) as the commonest type of ALRTI followed by Bronchiolitis (10.7\%). 
Our study results were also comparable to Srinivasa $S$ et al. [37]. bronchopneumonia was diagnosed in $42 \%$ of cases while Bronchiolitis and lobar pneumonia was diagnosed in $17 \%$ and $14 \%$ cases respectively. This is also comparable with the study done by Reddaiah et al. where they reported bronchopneumonia as a major LRTI [38]. Mungala VK et al. also reported bronchopneumonia as the commonest LRTI in their study [39].

\section{Conclusion}

Bronchopneumonia was the commonest LRTI in children with the predominance of VSD. We thus conclude that respiratory infections in children with congenital heart disease is common, however they have a good outcome. The majority of CHD lesions are Ventricular Septal defects while Bronchopneumonia was the most common diagnosis.

\section{Contribution by different authors}

Dr. Afsal conceptualized and designed the study, interpreted data, revised the manuscript and approved the final version to be published. He will act as the guarantor of the study. Dr. Sandeep acquired the data, drafted the article and helped in the final approval of the manuscript. Dr.Manjunath Babu analyzed the data, revised contents and helped in final approval.

\section{What does this study add to the existing Knowledge?}

Earlier it was believed that respiratory infections especially lower Respiratory Tract infections in a child with CHDs worsens the prognosis and outcome of these children but now with this study and similar studies it can be seen that Lower Respiratory Tract infections especially ones like Pneumonia can coexist with $\mathrm{CHDs}$ and can be diagnosed and treated early and in an efficient way and the outcome of these children is also good.

\section{Reference}

01. Broor S, Pandey RM, Ghosh M, Maitreyi RS, Lodha $R$, Singhal $T$, et al. Risk factors for severe acute lower respiratory tract infection in under-five children. Indian Pediatr. 2001 Dec;38(12)1361-9. [Crossref][PubMed][Google Scholar]
02. Graham NM. The epidemiology of acute respiratory infections in children and adults- a global perspective. Epidemiol Rev. 1990;12;149-78. doi: 10.1093/oxfordjournals.epirev.a036050 [Crossref] [PubMed][Google Scholar]

03. Berman S. Epidemiology of acute respiratory infections in children of developing countries. Rev Infect Dis. 1991 May-Jun;13 Suppl 6;S454-62. doi: 10.1093/clinids/13.supplement_6.s454 [Crossref] [PubMed][Google Scholar]

04. Cashat-Cruz M, Morales-Aguirre JJ, MendozaAzpiri M. Respiratory tract infections in children in developing countries. Semin Pediatr Infect Dis. 2005 Apr;16(2)84-92. doi: 10.1053/j.spid.2005.12.005 [Crossref][PubMed][Google Scholar]

05. Koch A, Mølbak K, Homøe P, Sørensen P, Hjuler $\mathrm{T}$, Olesen $\mathrm{ME}$, et al. Risk factors for acute respiratory tract infections in young Greenlandic children. Am J Epidemiol. 2003 Aug 15;158(4)374-84. doi: 10.1093/aje/kwg143 [Crossref][PubMed][Google Scholar]

06. Saeed AA, Bani IA. Prevalence and correlates of acute respiratory infections in children less than two years of age. Saudi Med J. 2000 Dec;21(12)1152-6. [Crossref][PubMed][Google Scholar]

07. Zaman K, Baqui $A H$, Yunus $M$, Sack RB, Bateman OM, Chowdhury $H R$, et al. Acute respiratory infections in children- a communitybased longitudinal study in rural Bangladesh. J Trop Pediatr. 1997 Jun;43(3)133-7. doi: 10.1093/tropej/43.3.133 [Crossref][PubMed] [Google Scholar]

08. Hajela S. "Profile of Congenital Heart Disease in childhood". surgery. 11(2014)12. [Crossref] [PubMed][Google Scholar]

09. Cross TJ, Kim CH, Johnson BD, Lalande S. The interactions between respiratory and cardiovascular systems in systolic heart failure. J Appl Physiol. 2020 Jan 1;128(1)214-224. doi: 10.1152/japplphysiol.00113.2019 [Crossref] [PubMed][Google Scholar]

10. Gabriela, Krystle, Rahmat Budi Kuswiyanto, and Fenny Dwiyatnaningrum. "Clinical characteristic and outcome of acute lower respiratory tract infection in children with congenital heart disease". Althea Medical Journal. 2;3(2015)403-408. [Crossref] [PubMed][Google Scholar] 
11. Cahyono, Agus, Machrus A Rachman. "The cause of mortality among congenital heart disease patients in Pediatric Ward, Soetomo General Hospital (2004-2006)". Indonesian Journal of Cardiology. (2007)279-284. [Crossref][PubMed] [Google Scholar]

12. Wilar Rocky, J M Wantania. "Beberapa faktor yang berhubungan dengan episode infeksi saluran pernapasan akut pada anak dengan penyakit jantung bawaan". Sari Pediatri. 8;2 (2016)154-8. [Crossref][PubMed][Google Scholar]

13. Nataprawira H M, E H Alwi, N Adriani. "Faktor risiko morbiditas dan mortalitas pneumonia berat pada anak usia balita". Majalah Kedokteran Indonesia. 60(2010)443-447. [Crossref][PubMed] [Google Scholar]

14. Lanata CF, Rudan I, Boschi-Pinto C, Tomaskovic $\mathrm{L}$, Cherian T, Weber M, et al. Methodological and quality issues in epidemiological studies of acute lower respiratory infections in children in developing countries. Int J Epidemiol. 2004 Dec;33(6)1362-72. doi: 10.1093/ije/dyh229 [Crossref][PubMed][Google Scholar]

15. Sommer C, Resch B, Simões EA. Risk factors for severe respiratory syncytial virus lower respiratory tract infection. Open Microbiol J. 2011;5;144-54. doi: 10.2174/1874285801105010144 [Crossref] [PubMed][Google Scholar]

16. Fauroux $B$, Simões EAF, Checchia PA, Paes $B$, Figueras-Aloy J, Manzoni $P$, et al. The Burden and Long-term Respiratory Morbidity Associated with Respiratory Syncytial Virus Infection in Early Childhood. Infect Dis Ther. 2017 Jun;6(2)173-197. doi: 10.1007/s40121-017-0151-4 [Crossref] [PubMed][Google Scholar]

17. Koch A, Mølbak K, Homøe P, Sørensen P, Hjuler $T$, Olesen $M E$, et al. Risk factors for acute respiratory tract infections in young Greenlandic children. Am J Epidemiol. 2003 Aug 15;158(4)374-84. doi: 10.1093/aje/kwg143 [Crossref][PubMed][Google Scholar]

18. Owayed AF, Campbell DM, Wang EE. Underlying causes of recurrent pneumonia in children. Arch Pediatr Adolesc Med. 2000 Feb;154(2)190-4. doi: 10.1001/archpedi.154.2.190 [Crossref][PubMed] [Google Scholar]
19. Hoffman JI, Kaplan S. The incidence of congenital heart disease. J Am Coll Cardiol. 2002 Jun 19;39(12)1890-900. doi: 10.1016/s07351097(02)01886-7 [Crossref][PubMed][Google Scholar]

20. Nguyen TK, Tran $T H$, Roberts CL, Fox GJ, Graham SM, Marais BJ. Risk factors for child pneumonia - focus on the Western Pacific Region. Paediatr Respir Rev. 2017 Jan;21;95-101. doi: 10.1016/j.prrv.2016.07.002 [Crossref][PubMed] [Google Scholar]

21. Zhang Q, Guo Z, Bai Z, MacDonald NE. A 4 year prospective study to determine risk factors for severe community acquired pneumonia in children in southern China. Pediatr Pulmonol. 2013 Apr;48(4)390-7. doi: 10.1002/ppul.22608 [Crossref][PubMed][Google Scholar]

22. Sadoh WE, Osarogiagbon WO. Underlying congenital heart disease in Nigerian children with pneumonia. Afr Health Sci. 2013 Sep;13(3)607-12. doi: 10.4314/ahs.v13i3.13 [Crossref][PubMed] [Google Scholar]

23. Pongiglione $G$, Possidoni $A$, di Luzio Paparatti $U$, Costanzo AM, Gualberti $G$, Bonvicini $M$, et al. Incidence of Respiratory Disease During the First Two Years of Life in Children with Hemodynamically Significant Congenital Heart Disease in Italy- A Retrospective Study. Pediatr Cardiol. 2016 Dec;37(8)1581-1589. doi: 10.1007/s00246-0161473-9 [Crossref][PubMed][Google Scholar]

24. Gabriela K, Kuswiyanto RB, Dwiyatnaningrum F. Clinical characteristic and outcome of acute lower respiratory tract infection in children with congenital heart disease. Althea Medical Journal. 2015 Sep 26;2(3)403-8. [Crossref][PubMed][Google Scholar]

25. Singh, Pankaj Kumar, Partha Kumar Chaudhuri, A $\mathrm{K}$ Chaudhary. "Incidence of congenital heart disease in children with recurrent respiratory tract infection in tertiary hospital". IOSR Journal of Dental and Medical Science. 16;9(2017)42-4. [Crossref] [PubMed][Google Scholar]

26. Şahan, Yasemin Özdemir, Erhan Kılıçoğlu, and Zülal Ülger Tutar. "Evaluation of children with congenital heart disease hospitalized with the Diagnosis of Lower Respiratory Tract Infection". The Journal of Pediatric Research. 5;1(2018)32. [Crossref][PubMed][Google Scholar] 
27. Margolis $P$, Gadomski A. The rational clinical examination, Does this infant have pneumonia?. JAMA. 1998 Jan 28;279(4)308-13. doi: 10.1001/jama.279.4.308 [Crossref][PubMed] [Google Scholar]

28. Jain S, Williams DJ, Arnold SR, Ampofo K, Bramley AM, Reed C, et al. Community-acquired pneumonia requiring hospitalization among US children. N Engl J Med. 2015 Feb 26;372(9)835-45. doi: 10.1056/NEJMoa1405870 [Crossref][PubMed] [Google Scholar]

29. Murphy CG, van de Pol AC, Harper MB, Bachur RG. Clinical predictors of occult pneumonia in the febrile child. Acad Emerg Med. 2007 Mar;14(3)2439. doi: 10.1197/j.aem.2006.08.022 [Crossref] [PubMed][Google Scholar]

30. Bachur $\mathrm{R}$, Perry $\mathrm{H}$, Harper MB. Occult pneumonias- empiric chest radiographs in febrile children with leukocytosis. Ann Emerg Med. 1999 Feb;33(2)166-73. doi: 10.1016/s01960644(99)70390-2 [Crossref][PubMed][Google Scholar]

31. Isaacs D. Problems in determining the etiology of community-acquired childhood pneumonia. Pediatr Infect Dis J. 1989 Mar;8(3)143-8. [Crossref] [PubMed][Google Scholar]

32. Hageman JC, Uyeki TM, Francis JS, Jernigan DB, Wheeler JG, Bridges CB, et al. Severe communityacquired pneumonia due to Staphylococcus aureus, 2003-04 influenza season. Emerg Infect Dis. 2006 Jun;12(6)894-9. doi: 10.3201/eid1206.051141 [Crossref][PubMed][Google Scholar]

33. Frazee, Bradley W. "Update on emerging infections: news from the Centers for Disease Control and Prevention, Severe methicillin-resistant Staphylococcus aureus community-acquired pneumonia associated with influenza--Louisiana and Georgia, December 2006-January 2007". Annals of emergency medicine. 50;5(2007)612-616. [Crossref][PubMed][Google Scholar]
34. Self WH, Williams DJ, Zhu Y, Ampofo K, Pavia AT, Chappell JD, et al. Respiratory Viral Detection in Children and Adults- Comparing Asymptomatic Controls and Patients With Community-Acquired Pneumonia. J Infect Dis. 2016 Feb 15;213(4)58491. doi: 10.1093/infdis/jiv323 [Crossref][PubMed] [Google Scholar]

35. Korppi M, Heiskanen-Kosma T, Kleemola M. Incidence of community-acquired pneumonia in children caused by Mycoplasma pneumoniaeserological results of a prospective, populationbased study in primary health care. Respirology. 2004 Mar;9(1)109-14. doi: 10.1111/j.14401843.2003.00522.x [Crossref][PubMed][Google Scholar]

36. Medrano C, Garcia-Guereta L, Grueso J, Insa B, Ballesteros F, Casaldaliga J, et al. Respiratory infection in congenital cardiac disease, Hospitalizations in young children in Spain during 2004 and 2005- the CIVIC Epidemiologic Study. Cardiol Young. 2007 Aug;17(4)360-71. doi: 10.1017/S104795110700042X [Crossref][PubMed] [Google Scholar]

37. Srinivasa S, Shruthi Patel. "A study on distribution pattern of lower respiratory tract infections in children under 5 years in a tertiary care centre". International Journal of Contemporary Pediatrics. 5;2(2018)456. [Crossref][PubMed] [Google Scholar]

38. Reddaiah V P, S K Kapoor. "Acute Respiratory Infections In Underfives- Experience At Comprehensive Rural Health Services Project Hospital, Ballabgarh". Indian Journal of Community Medicine. 20;2(1995)13. [Crossref][PubMed] [Google Scholar]

39. Munagala VK, Mahesh RMU, Kandat J, Ponugoti M. Clinical study of lower respiratory tract infection in children attending a tertiary care hospital. Int J Contemp Pediatr. 2017;4;1733-8. [Crossref] [PubMed][Google Scholar] 